Beata Gamrowska

http://dx.doi.org/10.18778/8142-336-6.04

beata.gamrowska@lib.uni.lodz.pl

Rafat Mielczarek

rafal.mielczarek@lib.uni.lodz.pl

Biblioteka Uniwersytetu Łódzkiego

\title{
STYLE MYŚLENIA O BIBLIOTECE DOBY CYFRYZACJI INSTYTUCJONALNA IDENTYFIKACJA BIBLIOTEKI
}

\begin{abstract}
Library remains the most important institution of social life. Its position is being set in a dialectical process in which social objectification of library bound to the institutional structure confronts ways that individual think about institution of library. That dialectical process is being shaped by number of factors connected to current civilizational environment - meaning cultural political and economic factors. One of them is Internet. The analysis given in the article is dedicated to the issue of Facebook influence on though style regarding institution of library as well as on the institutional identity of library.
\end{abstract}

Słowa kluczowe: biblioteka, instytucja, styl myślenia, Facebook

Stara i dobrze znana Heraklitejska sentencja pozwala uzmysłowić sobie, że refleksja nad miejscem jednostki w świecie oraz nad zmiennością samego świata ma długą historię. Ponadto, co oczywiste, jest nierozerwalnie spleciona z ewolucją krajobrazu społecznego i kulturowego. Naturalną niestabilność ludzkiej egzystencji zazwyczaj łagodzi wydatnie stabilność instytucji wypełniających ów krajobraz. Jednak gdy stabilność ta maleje lub zastępuje ją anomia, życie społeczne staje się chaotyczne i rodzą się pytania o przyczyny problemów i sposoby ich rozwiązania. Równocześnie z tym nurtem refleksji, która skupia się głównie na diagnozowaniu sytuacji aktualnej, rozwija się prognozowanie, zorientowane na rozmaite warianty przyszłości.

W tym odwiecznym procesie przejść od względnego porządku do kryzysu i z powrotem niezaprzeczalną rolę, której znaczenie trudno precyzyjnie oszacować, odgrywa ludzkie myślenie naturalnie uwikłane w społeczny i kulturowy kontekst. Powyższa prawidłowość objawia się na wszystkich poziomach życia zbiorowego, a więc dotyczy także funkcjonowania biblioteki jako instytucji społecznej. To znaczy, że jej pozycja w strukturze społecznej 
i funkcje są wynikiem dialektycznego procesu, w którym wiedza o instytucji i myślenie o niej tworzą splot w postaci dominującego stylu myślenia. Dziś dodatkowym i znaczącym czynnikiem w tym procesie stał się również Internet.

\section{Zmiana i niezmienne pytania}

Kwestie zawarte w metaforycznej formule tematu niniejszej monografii - miejsce współczesnej biblioteki w ewoluującym krajobrazie instytucjonalnym społeczeństwa oraz znaczenie tego miejsca - zapewne także wypływają ze źródeł niepokojów ożywianych gwałtownością zmian w ludzkim otoczeniu. Współczesny świat pod wieloma względami stał się faktycznie płynny, by użyć określenia Zygmunta Baumana. W tej sytuacji funkcjonowanie wielu instytucji, nie tylko tych z dziedziny kultury i nauki, nabrało dynamiki przekraczającej poziom umożliwiający rutynową kontrolę zorganizowanej działalności. Jednocześnie podniesione kwestie nie stanowią nowego wyzwania intelektualnego ani dla bibliotekoznawstwa, ani dla socjologii, której analityczną perspektywę zdecydowali się przyjąć autorzy prezentowanego tu artykułu. Postępująca szybko cyfryzacja zasobów bibliotecznych oraz coraz powszechniejsze wykorzystanie Internetu do udostępniania zdigitalizowanych zbiorów bez wątpienia znamionują nowy etap transformacji funkcji biblioteki, ewoluującej wraz z całym systemem społecznym. Jednak refleksja poświęcona zmiennym losom tej instytucji w społeczeństwie słowa drukowanego toczyła się na długo przed wynalezieniem Internetu, choć pojawienie się tego ostatniego z pewnością nadało zmianom większego tempa i w konsekwencji zintensyfikowało dyskusję. Jadwiga Kołodziejska przywołała sytuację z okresu międzywojennego, kiedy to ogólnemu szybkiemu rozwojowi polskiej państwowości towarzyszył równie szybki i intensywny rozwój myślenia o bibliotekach w kategoriach teoretycznych ${ }^{1}$.

Poczynione wyżej uwagi stanowią więc nie tylko konstatację faktów, ale także nieco rytualne przywołanie kwestii trwale obecnych $\mathrm{w}$ świadomości zbiorowej i powracających regularnie przy kolejnych odsłonach tematu zmiany. Refleksja bibliotekoznawcza, podobnie jak inne, rozwijane przez dhuższy czas, wytworzyła w tym zakresie kilka stałych presupozycji, takich jak przekonanie o istnieniu kryzysu i o jego długiej historii, wreszcie doszukiwanie się nowości głównie w aktualnym natężeniu zachodzących zmian, skali kryzysu.

${ }^{1}$ J. Kołodziejska, Biblioteki publiczne w strukturze społecznej, Warszawa 2010, s. 37. 
Bibliotekoznawstwo dzieli ten ogląd i wynikające z niego wnioski z wieloma innymi dyscyplinami z korpusu nauk społecznych.

Interesujący nas tutaj horyzont zmian wypełniają trzy zachodzące na siebie obszary. Pierwszy obszar wyznaczają globalne przemiany sfery publicznej, którą traktujemy jako najważniejszą sferę zakotwiczenia instytucjonalnego współczesnej biblioteki ${ }^{2}$. Drugi obszar wyznaczają toczące się wciąż procesy transformacji systemowej w Polsce, która doprowadziła na przestrzeni minionego ćwierćwiecza do przeorientowania świadomości zbiorowej w zakresie myślenia o wielu ważnych instytucjach społecznych. Trzeci obszar wyznacza transformacja systemu szkolnictwa wyższego w Polsce, w ramach którego funkcjonuje wybrana tu do analizy stylu myślenia o bibliotece - kategoria bibliotek akademickich ${ }^{3}$.

\section{Miejsce biblioteki w kulturze masowej}

Adam Łysakowski, jeden z luminarzy polskiego bibliotekarstwa, wyróżnił trzy główne etapy rozwoju bibliotek, które były w jego opinii ściśle związane $\mathrm{z}$ istniejącymi warunkami cywilizacyjnymi i charakteryzowały się wyraźną dominacją jednej funkcji organizacyjnej. W pierwszym okresie instytucje biblioteczne zajmowały się przede wszystkim gromadzeniem ksiąg (był to etap przypadający na okres od średniowiecza do XVII w.). W kolejnym etapie (od XVIII do połowy XIX w.) dominowało opracowanie zbiorów. W trzecim etapie, który przypadł na czas rozwoju kultury masowej, funkcją dominującą było udostępnianie zbiorów ${ }^{4}$. Ostatnie dekady były już traktowane przez badaczy

\footnotetext{
${ }^{2}$ Formuła zmian globalnych jest dziś niezwykle pojemna, przez co nieprecyzyjna. Używając jej mamy na myśli zachodni rdzeń cywilizacyjny owej globalności. Taka charakterystyka nie w każdym wypadku znajdzie swoje usprawiedliwienie. Jednak w przypadku instytucji biblioteki, analogicznie do instytucji szkoły, które są równie silnie wplecione w struktury społeczeństw niezachodnich, jak ma to miejsce w przypadku społeczeństw Zachodu, możemy w miarę bezpiecznie założyć, że kontekst zmian w bibliotece ma faktycznie zasięg globalny.

${ }^{3}$ Wybierając na przedmiot analizy tę dość szczególną kategorię bibliotek nie traktujemy jej jako kategorii reprezentatywnej dla ogółu bibliotek w Polsce, ani dla najogólniej pojmowanej kategorii współczesnej biblioteki w ogóle. Wybrana tu kategoria jest dla autorów raczej swoistym instytucjonalnym wzorem w rodzaju wzoru metra przechowywanego w Sèvres. Stąd też oraz ze względu na ograniczenie dotyczące rozmiaru tekstu zawęziliśmy dodatkowo zakres analizy do grupy 10 bibliotek akademickich z prawem do egzemplarza obowiązkowego.

${ }^{4}$ A. Łysakowski, Bibliotekarstwo naukowe: $z$ uwzględnieniem dokumentacji naukowo-technicznej, Warszawa 1956, s. 16-19.

${ }^{5}$ Zob.: M. Dembowska, Nowy ksztalt biblioteki $i$ nowoczesne bibliotekoznawstwo, [w:] red. A. Jarosz, Materiaty do studiowania bibliotekoznawstwa i informacji naukowej, t. 3, Bibliotekarstwo, Katowice 1980, s. 7.
} 
problemu jako kolejne stadium ewolucji funkcji, które charakteryzowała rosnąca rola działalności informacyjnej ${ }^{5}$.

Podobną perspektywę patrzenia na problem prezentował Jerzy Ratajewski, inny z grona badaczy bibliotekoznawców, który zwrócił uwagę, że rola i miejsce biblioteki stają się zrozumiałe na tle ustroju gospodarczego, społecznego i politycznego danego społeczeństwa. Przy czym uczony ten kładł mocny akcent na rangę makrostrukturalnego kontekstu podejmowanych analiz. Twierdził, iż by zrozumieć meandry zmian w instytucji biblioteki, trzeba wyjść poza wąskie ramy porządku organizacyjnego, który nadaje i pozwala utrzymać tejże instytucji wąską organizacyjną identyfikację. Sam Ratajewski wskazywał na możliwość poszerzenia pola analizy poprzez ujmowanie biblioteki w kontekście systemowym. Wówczas jej tożsamość, jako systemu społecznego, określałaby jej nadrzędna funkcja społeczna. Z tego punktu widzenia biblioteka mogłaby być ujmowana jako jeden $\mathrm{z}$ następujących systemów: system pamięci społecznej, system informacji i komunikacji społecznej, zakład pracy, ale także przedsiębiorstwo usługowe ${ }^{6}$.

Zmiany społecznych funkcji biblioteki szły w parze z jej przesunięciami $\mathrm{w}$ porządku struktury instytucjonalnej. Biblioteka, która w okresie dwóch pierwszych wymienionych wyżej etapów stanowiła część innych instytucji rozmaitych szczebli i rodzajów, takich jak dwór, rada miejska, klasztor ${ }^{7}$, z czasem, $^{2}$ w nowoczesnym społeczeństwie, zyskała samodzielność instytucjonalną i duże znaczenie dla rozwoju i trwałości takich filarów demokratycznego społeczeństwa jak nowoczesna autonomiczna nauka oraz pluralistyczna sfera publiczna ${ }^{8}$. Ten wzrost rangi dobrze thumaczy specyfika kultury masowej, w ramach której książka stała się powszechnie dostępnym dobrem, a biblioteka jednym z głównych ogniw w łańcuchu upowszechniania słowa drukowanego ${ }^{9}$. W mocno zurbanizowanym społeczeństwie prywatne kolekcje nie byłyby już w stanie zapewnić wystarczającego dostępu do rosnącej ilości produkcji literackiej

\footnotetext{
${ }^{6}$ Zob. J. Ratajewski, Wprowadzenie do bibliotekoznawstwa czyli wiedza o bibliotece w różnych dawkach, Warszawa 2002, s. 15-16.

${ }^{7}$ Ibidem, s. 13.

${ }^{8}$ Należy w tym miejscu nadmienić, że niektóre funkcje biblioteki jako instytucji społecznej mają charakter ambiwalentny, to znaczy mogą służyć różnym, nierzadko wręcz wykluczającym się celom. W tym konkretnym przypadku celom sprzecznym zasadniczo z istnieniem ładu demokratycznego. Na przykład informowanie może jednocześnie spełniać funkcję indoktrynacyjną. W efekcie można wyobrazić sobie hipotetyczną sytuację, w której biblioteka może służyć ograniczaniu pluralizmu i swobody myślowej w sferze publicznej oraz przeciwstawiać się autonomii nauki.

${ }^{9} \mathrm{Na}$ temat kultury masowej patrz: A. Kłoskowska, Kultura masowa. Krytyka i obrona, Warszawa 2005. Szczególnie dwa rozdziały: Określenie kultury masowej oraz Historyczne warunki powstania kultury masowej.
} 
i informacji prasowej nawet dla ich posiadaczy. Zdemokratyzowanie dostępu do drukowanych materiałów wymagało wypracowania standardów ich gromadzenia i opracowywania oraz upubliczniania zasobów.

Współczesna biblioteka, kojarzona powszechnie ze sferą publiczną, nie miała takiej pozycji w momencie narodzin owej sfery, mimo iż to właśnie literatura była jedną z najważniejszych płaszczyzn debaty politycznej. Znamienne, że Jurgen Habermas w swojej klasycznej już dziś książce, poświęconej procesom formującym sferę publiczną dzisiejszej demokracji, nie wymienił biblioteki w grupie instytucji, które pod koniec XVIII w. miały wpływ na ówczesne zmiany polityczne ${ }^{10}$. Biblioteka epoki narodzin nowoczesnej demokracji to wciąż ,pokój biblioteczny - pałacu, dworu czy mieszczańskiego apartamentu, to miejsce o szczególnej powadze, w którym zastaje się najczęściej pana domu, kiedy $\mathrm{w}$ godzinach wolnych od pracy oddaje się bardziej bezinteresownym zajęciom. Nie oznacza to koniecznie czytania, może tu bowiem wchodzić w grę np. palenie ulubionej fajki" ${ }^{11}$. Dziś biblioteka publiczna jest już bez wątpienia przestrzenią obywatelskiej edukacji, mimo iż nierzadko tego niezaprzeczalnego wkładu nie dostrzegają i nie doceniają osoby decydujące o finansowaniu działalności bibliotek. Grzegorz Makowski i Filip Pazderski stwierdzili, iż biblioteki są wręcz ,predestynowane do wykonywania zadań z zakresu nieformalnej edukacji obywatelskiej”'12. Tu należy dodać, iż szczególnie predestynowane zdają się te rozsiane po małych prowincjonalnych ośrodkach miejskich, zazwyczaj pozbawionych szeregu instytucji, których obecność w krajobrazie dużych miast jest traktowana jako coś naturalnego. W tych miejscach instytucja biblioteki jest zarówno ogniwem organizacji państwowej, jak też sferą demokracji. Przywołani autorzy wspierają swoją opinię dwoma przekonywującymi argumentami. Po pierwsze biblioteka funkcjonuje w formule instytucji publicznej, co oznacza jej otwartość na wszystkich bez względu na społeczny status. Po wtóre, ten publiczny, a więc określany przez państwo charakter instytucji biblioteki sprawia, że niemal automatycznie staje się ona obszarem styczności obywatela z państwem, a więc także miejscem podnoszenia kwalifikacji obywatelskich ${ }^{13}$. Wspomniane wyżej problemy z wykorzystaniem tego potencjału wynikają z negatywnych skutków transformacji ideologicznej perspektywy, która organizuje planowanie zadań na szczeblu organizacyjnym.

${ }^{10}$ J. Habermas, Strukturalne przeobrażenia sfery publicznej, red. M. Czyżewski, Warszawa 2007. Szczególnie rozdział Instytucje sfery publicznej.

${ }^{11}$ M. Czerwiński, System ksiażki, Warszawa 1976, s. 160.

${ }^{12}$ G. Makowski, F. Pazderski, Biblioteki publiczne jako przestrzeń nieformalnej edukacji obywatelskiej, „Analizy i Opinie” 2011, nr 116, s. 6.

${ }^{13}$ Ibidem. 
Szerokie horyzonty planów z epoki realnego socjalizmu potraktowano jako myślenie zbyt abstrakcyjne, przez co oderwane od rzeczywistości i w ich miejsce przyjęto zasadę oglądu i planowania spraw w o wiele węższym horyzoncie. $\mathrm{Z}$ takiej zawężonej perspektywy automatyzacja gminnej biblioteki faktycznie wydaje się fanaberią, bo owoce tych działań pojawią się w bardzo odległym horyzoncie, aczkolwiek trudno znaleźć głosy polemizujące $\mathrm{z}$ celowością i potrzebą rozwijania tego typu instytucji. W praktyce jednak w rywalizacji o środki niemal zawsze zwycięży droga gminna lub inne bieżące potrzeby ${ }^{14}$.

Biblioteki w Polsce są dziś traktowane jako składnik kapitału intelektualnego ${ }^{15}$, co już w warstwie języka opisu wskazuje na przekształcenie ich społecznego wizerunku $\mathrm{w}$ obraz organizacji o spragmatyzowanych funkcjach i celach, jednocześnie w opinii potocznej nadal cieszą się estymą instytucji realizujących misję społeczną. Nie ma wzmianki o bibliotekach w Raporcie o $\mathrm{Ka}$ pitale Intelektualnym Polski z 2008 r., przygotowanym przez Zespół Doradców Strategicznych Prezesa Rady Ministrów kierowany przez Pawła Bochniarza ${ }^{16}$. Wątek biblioteki został podjęty jedynie w dwóch z trzech zwycięskich projektów, które zostały zgłoszone na konkurs Ministerstwa Nauki i Szkolnictwa Wyższego „na założenia do ustawy Prawo o szkolnictwie wyższym”" ${ }^{17}$. Natomiast oceny zasobów bibliotek, zawarte w raporcie z konsultacji, jakie przeprowadził zespół z Instytutu Allerhanda, wypadają zdecydowanie pozytywnie i zgodnie. Obie grupy - kadra akademicka, jak i pracownicy administracyjni - oceniły ten aspekt funkcjonowania własnej uczelni dobrze i bardzo dobrze. W przypadku kadry akademickiej suma ocen pozytywnych wyniosła w przybliżeniu $66 \%$ przy $11 \%$ ocen negatywnych, w przypadku pracowników administracyjnych bez mała $80 \%$ oceniło ten aspekt pozytywnie przy niecałych $4 \%$

${ }^{14}$ A. Sobótka, K. Wołodźko, Dokąd zmierzasz biblioteko?, „Nowy Obywatel” 2011, nr 3, s. 52. Również Jadwiga Kołodziejska zwróciła uwagę na charakterystyczne dla obecnej debaty publicznej przenoszenie wolnorynkowych schematów myślenia o organizacji życia ekonomicznego na wszystkie płaszczyzny życia społecznego, najczęściej ze szkodą dla tych zazwyczaj fundamentalnych dla systemu demokratycznego działań, które z założenia nie mogą być rentowne. Idem, Biblioteki publiczne..., s. 132.

${ }^{15}$ Patrz: J. Kołodziejska, Biblioteki publiczne w strukturze społecznej, s. 129 i n.

${ }^{16}$ Raport o Kapitale Intelektualnym Polski z dnia 10 lipca 2008, http://kramarz.pl/Raport 2008_Kapital_Intelektualny_Polski.pdf, [dostęp: 30.05.2017].

${ }^{17}$ Mowa o następujących projektach. „Propozycja założeń do ustawy regulującej system szkolnictwa wyższego" opracowana przez Zespół Interdyscyplinarny pod kierownictwem Huberta Izdebskiego z Uniwersytetu SWPS; „Projekt zalożeń do ustawy Prawo o szkolnictwie wyższym” przygotowany przez zespół pod kierownictwem Marka Kwieka z UAM; „Plus ratio quam vis consuetudinis Reforma nauki i akademii w Ustawie 2.0. Projekt zatożeń do ustawy Prawo o szkolnictwie wyższym", red. A. Radwan z Instytutu Allerhanda. Teksty propozycji dostępne są na stronie internetowej Ministerstwa Nauki i Szkolnictwa Wyższego, http://www.nau ka.gov.pl/ustawa20/, [dostęp: 30.05.2017]. 
ocen negatywnych w sumie (tab. 1 i 2 ). W obu przypadkach ten aspekt został oceniony najwyżej spośród odpowiednio 14 aspektów ocenionych przez kadrę naukową i 15 aspektów ocenionych przez pracowników administracyjnych. Interpretując te dane można wskazać na dwie możliwości, bez różnicowania punktu widzenia przedstawicieli obu grup. W pierwszym przypadku, jeśli oceny są adekwatne do stanu faktycznego zasobów bibliotecznych, to mogą odzwierciedlać troskę społeczną i środowiskową o ten aspekt funkcjonowania

Tabela 1

Ocena różnych aspektów funkcjonowania własnej uczelni (kadra naukowa)

\begin{tabular}{|l|c|c|c|c|c|}
\hline \multicolumn{1}{|c|}{ Aspekty } & $\begin{array}{c}\text { Bardzo } \\
\text { źle (\%) }\end{array}$ & $\begin{array}{c}\text { Raczej } \\
\text { źle (\%) }\end{array}$ & $\begin{array}{c}\text { Średnio } \\
(\%)\end{array}$ & $\begin{array}{c}\text { Raczej } \\
\text { dobrze (\%) }\end{array}$ & $\begin{array}{c}\text { Bardzo } \\
\text { dobrze (\%) }\end{array}$ \\
\hline $\begin{array}{l}\text { Organizację Uczelni, w której } \\
\text { Pan /Pani pracuje }\end{array}$ & 5,35 & 17,72 & 39,11 & 32,80 & 5,03 \\
\hline $\begin{array}{l}\text { Funkcjonowanie pionu } \\
\text { administracji w Pana/Pani } \\
\text { Uczelni }\end{array}$ & 11,58 & 26,71 & 33,27 & 23,81 & 4,63 \\
\hline $\begin{array}{l}\text { Funkcjonowanie dydaktyki } \\
\text { w Pana/Pani Uczelni }\end{array}$ & 3,53 & 15,36 & 34,38 & 38,37 & 8,35 \\
\hline $\begin{array}{l}\text { Możliwość pracy naukowej na } \\
\text { Pan/i Uczelni }\end{array}$ & 6,72 & 20,74 & 33,98 & 30,43 & 8,14 \\
\hline $\begin{array}{l}\text { Funkcjonowanie pionu badań } \\
\text { i rozwoju w Pana/Pani Uczelni }\end{array}$ & 10,66 & 28,52 & 35,14 & 20,91 & 4,77 \\
\hline $\begin{array}{l}\text { Współpracę Pana/Pani Uczelni } \\
\text { z otoczeniem społeczno- } \\
\text { gospodarczym }\end{array}$ & 11,76 & 29,04 & 35,35 & 20,07 & 3,79 \\
\hline $\begin{array}{l}\text { Współpracę w Pana/Pani Uczelni } \\
\text { z Uczelniami zagranicznymi } \\
\text { (w tym w zakresie mobilności } \\
\text { pracowników naukowych) }\end{array}$ & 6,80 & 21,44 & 32,75 & 28,50 & 10,52 \\
\hline $\begin{array}{l}\text { Efektywność zarządzania } \\
\text { finansami Pana/Pani Uczelni }\end{array}$ & 11,56 & 25,08 & 36,71 & 21,91 & 4,73 \\
\hline $\begin{array}{l}\text { Stan infrastruktury badawczej } \\
\text { Pana/Pani Uczelni }\end{array}$ & 8,28 & 19,01 & 32,25 & 30,93 & 9,54 \\
\hline $\begin{array}{l}\text { Stan bazy dydaktycznej Pana/ } \\
\text { Pani } \\
\text { Uczelni }\end{array}$ & 5,17 & 15,20 & 28,91 & 38,94 & 11,77 \\
\hline Bazę lokalową Pana/Pani Uczelni & 4,50 & 11,82 & 23,19 & 38,86 & 21,64 \\
\hline $\begin{array}{l}\text { Zasoby biblioteki Pana/Pani } \\
\text { Uczelni }\end{array}$ & $\mathbf{2 , 9 2}$ & $\mathbf{8 , 3 1}$ & $\mathbf{2 2 , 7 9}$ & $\mathbf{4 2 , 8 6}$ & $\mathbf{2 3 , 1 2}$ \\
\hline $\begin{array}{l}\text { Współpracę z innymi } \\
\text { pracownikami akademickimi }\end{array}$ & 2,85 & 10,29 & 27,57 & 41,75 & 17,54 \\
\hline $\begin{array}{l}\text { Współpracę z pracownikami } \\
\text { administracji }\end{array}$ & 6,49 & 15,74 & 31,79 & 33,33 & 12,65 \\
\hline
\end{tabular}

Źródło: Raport z konsultacji społecznych założeń nowej ustawy prawo o szkolnictwie wyższym opracowanych przez Instytut Allerhanda w ramach projektu Ustawa 2.0, s. 24-25, http://www.nauka.gov.pl/ustawa20/, [dostęp: 15.05.2017]. 
uczelni, a więc utrzymujące się na wysokim poziomie społeczne znaczenie bibliotek i ich zasobów. W drugim przypadku, jeśli ocena jest na wyrost, można potraktować ją również jako odzwierciedlenie wciąż wysokiej społecznej rangi bibliotek i ich zasobów, tyle że tutaj oddziaływującej poprzez stereotyp determinujący wysoką ocenę omawianego aspektu.

Tabela 2

Ocena różnych aspektów funkcjonowania własnej uczelni (kadra administracyjna)

\begin{tabular}{|l|c|c|c|c|c|}
\hline \multicolumn{1}{|c|}{ Aspekty } & $\begin{array}{c}\text { Bardzo } \\
\text { źle (\%) }\end{array}$ & $\begin{array}{c}\text { Raczej } \\
\text { źle (\%) }\end{array}$ & $\begin{array}{c}\text { Trudno } \\
\text { powiedzieć } \\
(\%)\end{array}$ & $\begin{array}{c}\text { Raczej } \\
\text { dobrze } \\
(\%)\end{array}$ & $\begin{array}{c}\text { Bardzo } \\
\text { dobrze } \\
(\%)\end{array}$ \\
\hline $\begin{array}{l}\text { Ogólnie funkcjonowanie całej uczelni, } \\
\text { w której Pan/Pani pracuje }\end{array}$ & 1,19 & 11,02 & 39,66 & 40,68 & 7,46 \\
\hline $\begin{array}{l}\text { Funkcjonowanie pionu administracji } \\
\text { w Pana/Pani uczelni }\end{array}$ & 2,55 & 15,45 & 38,54 & 36,67 & 6,79 \\
\hline $\begin{array}{l}\text { Jakość badań naukowych na polskich } \\
\text { uczelniach }\end{array}$ & 3,85 & 18,69 & 45,09 & 26,01 & 6,36 \\
\hline $\begin{array}{l}\text { Funkcjonowanie dydaktyki w Pana/ } \\
\text { Pani uczelni }\end{array}$ & 1,27 & 14,73 & 36,36 & 41,09 & 6,55 \\
\hline $\begin{array}{l}\text { Funkcjonowanie pionu badań } \\
\text { i rozwoju w Pana/Pani uczelni }\end{array}$ & 5,15 & 19,60 & 39,21 & 27,52 & 8,51 \\
\hline $\begin{array}{l}\text { Współpracę Pana/Pani uczelni } \\
\text { z otoczeniem społeczno- } \\
\text { gospodarczym }\end{array}$ & 6,43 & 21,17 & 38,00 & 27,60 & 6,81 \\
\hline $\begin{array}{l}\text { Współpracę w Pana/Pani uczelni } \\
\text { z uczelniami zagranicznymi (w tym } \\
\text { w zakresie mobilności pracowników } \\
\text { naukowych) }\end{array}$ & 3,70 & 15,79 & 37,04 & 31,58 & 11,89 \\
\hline $\begin{array}{l}\text { Efektywnó́ć zarządzania finansami } \\
\text { Pana/Pani uczelni }\end{array}$ & 6,57 & 24,95 & 34,33 & 27,77 & 6,38 \\
\hline Stan infrastruktury Pana/Pani uczelni & 2,09 & 9,95 & 29,84 & 44,50 & 13,61 \\
\hline $\begin{array}{l}\text { Poziom bazy dydaktycznej Pana/Pani } \\
\text { uczelni }\end{array}$ & 1,65 & 8,64 & 31,62 & 43,38 & 14,71 \\
\hline Stan bazy lokalowej Pana/Pani uczelni & 2,29 & 6,87 & 28,17 & 47,01 & 15,67 \\
\hline $\begin{array}{l}\text { Zasoby biblioteki Pana/Pani } \\
\text { uczelni }\end{array}$ & $\mathbf{0 , 3 7}$ & $\mathbf{3 , 3 6}$ & $\mathbf{1 6 , 7 9}$ & $\mathbf{4 9 , 4 4}$ & $\mathbf{3 0 , 0 4}$ \\
\hline $\begin{array}{l}\text { Współpracę administracji } \\
\text { z pracownikami naukowymi }\end{array}$ & 3,15 & 13,46 & 29,55 & 40,38 & 13,46 \\
\hline $\begin{array}{l}\text { Współpracę z innymi pracownikami } \\
\text { uczelni nie pracującymi w działach } \\
\text { administracji }\end{array}$ & 0,72 & 6,86 & 29,60 & 49,46 & 13,36 \\
\hline $\begin{array}{l}\text { Współpracę z innymi jednostkami } \\
\text { administracji na Uczelni }\end{array}$ & 1,73 & 11,09 & 29,46 & 46,27 & 11,44 \\
\hline
\end{tabular}

Źródło: Raport z konsultacji społecznych założeń nowej ustawy prawo o szkolnictwie wyższym opracowanych przez Instytut Allerhanda w ramach projektu Ustawa 2.0, s. 24-25, http://www.nauka.gov.pl/ustawa20/, [dostęp: 15.05.2017]. 


\section{Społeczny kontekst myślenia o bibliotece}

Marcin Czerwiński wyraził opinię, że te cywilizacyjne przemiany, które dały instytucjonalną autonomię bibliotekom, a rzeszom czytelników szeroki dostęp do książek i prasy, nie zmieniły zasadniczo społecznego funkcjonowania książki. Zmieniły natomiast, i to bardzo, wyobrażenie o książkach. Książka straciła walor dobra trwałego, stacjonarnego przekazu. W świadomości społecznej pojawił się obraz rotacji tytułów, strumienia wydarzeń wydawniczych, co w opinii Czerwińskiego upodobniło system książki do systemu środków masowego przekazu i w konsekwencji sprawiło, że biblioteka przestała być naczelną for mą obecności książki. Socjolog zwracał uwagę, iż czynnikiem osłabiającym pozycję bibliotek publicznych jest, paradoksalnie, rodzaj snobizmu, który czyni posiadanie książek przejawem symbolicznej przynależności do elity społecznej ${ }^{18}$. Pozycję bibliotek, co sygnalizowano już na wstępie tych rozważań, kształtuje też ich społeczny stereotyp. Kołodziejska zwróciła uwagę, iż w kulturze polskiej instytucja biblioteki była postrzegana jako integralny element instytucjonalnej struktury państwa. Ten obraz funkcjonował już w okresie międzywojennym, został zaś wzmocniony w okresie PRL, kiedy państwo kontrolowało wszystkie ważne aspekty życia codziennego. Ten stereotyp utrudniał jej zdaniem odpaństwowienie i uspołecznienie bibliotek ${ }^{19}$. Kołodziejska dostrzegała, podobnie jak niegdyś dyfuzjoniści, że kultura duchowa (w tym biblioteka jako instytucja kultury) nie poddaje się zmianom z taką łatwością jak kultura materialna.

Dziś warta odnotowania jest wyraźna zmiana w postrzeganiu roli czytelników w kształtowaniu sytuacji biblioteki, którą to zmianę daje się wychwycić w najnowszych analizach bibliotekoznawczych, gdy porównamy je z tymi sprzed bez mała półwiecza. W 1973 r. Aleksandra Mściszowa, analizując ówczesną sytuację zawodu bibliotekarza, rysowała obraz, który językiem wyrazu przypominał charakterystykę zjawiska aglomeracji, zawartą w Buncie mas, klasycznym dziele José Ortegi y Gasseta ${ }^{20}$. W tekście Mściszowej możemy przeczytać, że „masowy napływ czytelników, lawina druków zalewająca biblioteki czyni je podobnymi do zakładów produkcyjnych nastawionych na wysokie obroty” oraz dalej, że proces ten generuje „problem techniczny opanowania sytuacji, metodycznej organizacji i usprawnienia pracy w bibliotekach” i w konsekwencji prowadzi do sytuacji, w której „środki

\footnotetext{
${ }^{18}$ M. Czerwiński, System książki, Warszawa 1976, s. 28-29.

${ }^{19}$ J. Kołodziejska, Kultura. Gospodarka. Biblioteki, Warszawa 1992, s. 54.

${ }^{20}$ Ortega y Gasset pisał o zjawisku aglomeracji, które cechowała wszechobecna pełność, a nawet przepełnienie, ustanawiane przez „tłum jako taki, korzystający ze stworzonych przez cywilizację pomieszczeń i urządzeń”; idem, Bunt mas, Warszawa 1995, s. 8.
} 
biurowo-techniczne i fotomechaniczne nabierają takiego znaczenia, iż grożą, że staną się głównym celem i zadaniem bibliotekarstwa"21. Jednocześnie cytowana analiza pozwala stwierdzić, że ówczesna biblioteka wciąż pozostawała instytucją, w ramach której dwie główne, związane z jej działalnością grupy - bibliotekarze i czytelnicy - wciąż praktykowały odmianę tradycyjnego etosu inteligenckiego. Pytając o kierunek zmian w zawodzie, Mściszowa sięgała do łacińskiego credo dziewiętnastowiecznego niemieckiego bibliotekarza, Fryderyka A. Eberta - „służąc innym sam spalam się” (Aliis serviendo consumor) i sugerowała „'Aliis serviendo cresce!' [służąc innym wzrastam (w wiedzy) - R.M.] - powinniśmy powiedzieć sobie dzisiaj. Jeśli mamy udzielać porad naszym czytelnikom, być lekarzami wiedzy (...)”22.

Ponad trzydzieści lat później miejsce nieco futurologicznych spekulacji o ewolucji istoty profesji bibliotekarza zajęło niezwykle konkretne pytanie o szanse na przetrwanie zawodu w najbliżej przyszłości. Diagnozy wskazywały, że kryzys trwał, a jego źródłem pozostawała aktywność mas. Tym razem jednak problemem nie było wskazywane już przez Ortegę y Gasseta przepełnienie, lecz pustoszenie, które szczególnie boleśnie zaczęło dotykać biblioteki. W 2006 r., podczas Sesji „Przeszłość i przyszłość”, II Konferencji Biblioteki Politechniki Łódzkiej pod tytułem „Biblioteki XXI wieku. Czy przetrwamy?", Di Martin, ówczesna Dziekan ds. Nauczania i Informacji Uniwersytetu w Hertfordshire, pisała: „We have seen a lot of change over the last decade, but the critical difference for us now is that the pace of change is exponential now that a high percentage of the population has become a mass market of digital citizens. Now as librarians you are asking 'Will we survive?",23. $\mathrm{W}$ istniejącym obecnie cyfrowym środowisku (digital environment) masowego rynku (mass market) czytelnik szukający wiedzy stał się więc cyfrowym obywatelem (digital citizen) oraz klientem (customer) z określonymi preferencjami i oczekiwaniami odnoszącymi się do usług, jakich wymaga od usługodawcy (service provider) oraz, co tutaj najważniejsze, z olbrzymią ilością alternatyw w dostępnej ofercie. W konsekwencji biblioteka straciła monopol na gromadzenie i udostępnianie wiedzy, który opierał się na strategicznym usytuowaniu w instytucjonalnej strukturze społeczeństwa ostatnich dwóch stuleci. W strukturze sieci internetowej biblioteka spadła na

${ }^{21}$ A. Mściszowa, Ksztaltowanie się zawodu bibliotekarskiego, [w:] red. A. Jarosz, Materiaty do studiowania bibliotekoznawstwa i informacji naukowej, t. 3, Bibliotekarstwo, Katowice 1980, s. 38-39.

${ }^{22}$ Ibidem.

${ }^{23}$ D. Martin, Bright futures: getting a sense of direction, [w:] Biblioteki XXI wieku. Czy przetrwamy? II Konferencja Biblioteki Politechniki Łódzkiej, Łódź, 19-21 czerwca 2006 r.: materiaty konferencyjne, praca zbiorowa, Łódź 2006, s. 12. 
pozycję jednego $\mathrm{z}$ wielu węzłów koncentrujących informacje (choć wciąż cieszy się pewnymi przywilejami ${ }^{24}$. Dlatego też, według sugestii Martin, bibliotekarza w roli lekarza wiedzy powinien zastąpić bibliotekarz w roli usługodawcy, który zasadniczo nie będzie się różnić od sprzedawców usług komercyjnych. „So we must think about the expectations of our digital citizen users. We need to shift the focus of our thinking to people, to our customers and their expectations, and not just to the technology" - konkludowała Martin ${ }^{25}$.

\section{Informacje w Internecie - problem bańki informacyjnej}

Przez ostatnie dwie dekady Internet pozostaje przedmiotem rosnącego ogólnego zainteresowania. Wynika to faktu, iż w tym stosunkowo krótkim czasie jego obecność w bardzo wielu dziedzinach życia, często o znaczeniu pierwszorzędnym, nie tylko zmieniła odczuwalnie warunki ludzkiego życia, ale równie dynamicznie zmieniła sam Internet. W związku z powyższym w naturalny sposób przyciągał on także zainteresowanie badaczy z obszaru nauk społecznych. Trudno tu zrekonstruować tą wielowątkową dyskusję, ponieważ już samo to przekroczyłoby dopuszczalne ramy niniejszej publikacji. Niżej przywołany zostanie jeden z krytycznych i poznawczo wartościowych głosów, którego nie powinno się pomijać w refleksji podejmującej problematykę zbiorowej świadomości funkcjonującej w zinternetyzowanym społeczeństwie.

Wspomniany głos należy do dziennikarza Wojciecha Orlińskiego, autora licznych publikacji publicystycznych z zakresu popkultury. Ten głos ${ }^{26}$, o wyraźnym brzmieniu kasandrycznym, wychodzi z perspektywy odmiennej od tej, która dominuje w refleksji poświęconej Internetowi. Uogólniając bardzo charakterystykę tej dominującej perspektywy, można opisać ją za pomocą dwóch podstawowych założeń, na których się opiera. Po pierwsze Internet jest medium przekazu informacji. Jako taki, jest kolejnym stadium w rozwoju technologii komunikacyjnych. To założenie jest podstawą drugiego, które zawiera już w sobie komponent oceny społecznej i kulturowej wartości tegoż medium. Drugie założenie wyraża dość powszechne przekonanie, że Internet jest medium, które niesie ze sobą o wiele więcej szans niż zagrożeń dla życia

\footnotetext{
${ }^{24}$ Notabene schemat, którym autorka zilustrowała swoją analizę transformacji modelu biblioteki, wykorzystuje również symbolikę chmur. W świetle tej poetyki biblioteka przechodzi od etapu chmur nad, które reprezentują wydawców, do etapu funkcjonowania w chmurze, reprezentującej Internet.

${ }^{25}$ D. Martin, op. cit., s. 12.

${ }^{26}$ Zob. W. Orliński, Internet. Czas się bać, Warszawa 2013. W niniejszym artykule rekonstruujemy tezy zawarte w rozdziale „Jak straciliśmy dostęp do informacji”.
} 
społecznego i trwałości kultury w tej jej formie, do której są mocno przywiązani ludzie Zachodu. To przekonanie nie oznacza zaślepienia tak charakterystycznego dla rozmaitych odmian skrajnego optymizmu. Oznacza ono jednak, że z punktu widzenia prezentowanej perspektywy suma korzyści, jakie daje Internet, przewyższają zdecydowanie sumę kosztów, które również generuje.

Orliński polemizuje $\mathrm{z}$ takimi kalkulacjami, ponieważ jego zdaniem już pierwsze $\mathrm{z}$ wymienionych wyżej założeń jest błędne. $\mathrm{W}$ jego opinii realia świadczenia usług przez niezwykle dziś popularne portale społecznościowe, takie jak Facebook, upodabnia Internet bardziej do domeny świadczeń użyteczności publicznej (public utility) niż do mediów. U podstaw tego błędu leży coś, co niezwykle nieprecyzyjnie można nazwać naturą ludzką współczesnego człowieka $\mathrm{i}$ ten jej mechanizm, który każe mu dopatrywać się w zachodzących zmianach realizacji jakiegoś planu. Stąd też - i odnotowuje to sam Orliński - ,jako społeczeństwa wciąż popełniamy ten sam błąd, obserwując postęp cyfrowych technologii. Gdy widzimy jakąś nową usługę, wydaje się nam, że będzie ona interesującym uzupełnieniem istniejących - że te nowe przychodzą tu po to, żeby unicestwić te stare, uświadamiamy sobie dopiero, gdy jest za późno, 27 .

\section{Obraz biblioteki akademickiej na Facebooku}

Do analizy stylu myślenia o bibliotece i formułujących się w nim podstawowych form wybraliśmy profile facebookowe 10 bibliotek akademickich, które znajdują się na liście bibliotek uprawnionych do otrzymywania egzemplarza obowiązkowego. Z tej grupy wypadła Biblioteka Główna Uniwersytetu Opolskiego, która w momencie badania nie posiadała swojego profilu na Facebooku. Pozostałe 9 placówek to w kolejności porządku alfabetycznego:

- $\quad$ Biblioteka Główna Uniwersytetu Gdańskiego (BUG);

- Biblioteka Główna Uniwersytetu Marii Curie-Skłodowskiej w Lublinie (BUMCS);

- $\quad$ Biblioteka Jagiellońska (BJ);

- Biblioteka Uniwersytecka Katolickiego Uniwersytetu Lubelskiego Jana Pawła II (BKUL);

- $\quad$ Biblioteka Uniwersytetu Adama Mickiewicza w Poznaniu (BUAM);

- Biblioteka Uniwersytetu Łódzkiego (BUŁ);

- $\quad$ Biblioteka Uniwersytetu Mikołaja Kopernika w Toruniu (BUMK);

- $\quad$ Biblioteka Uniwersytetu Warszawskiego (BUW);

- Biblioteka Uniwersytetu Wrocławskiego (BUWr).

${ }^{27}$ Ibidem, s. 26. 
Przedmiot badania stanowiły treści wpisów publikowanych przez osoby redagujące profil określonej biblioteki z ramienia tejże placówki oraz treści komentarzy osób odwiedzających profil biblioteki, które zostały zainicjowane wspomnianymi wpisami. Wybór tych dwóch określonych rodzajów wypowiedzi medialnych był motywowany założeniem, iż ich forma oraz kontekst instytucjonalny stworzą warunki, w których będą się odzwierciedlać kategorie myślenia o bibliotece aktualnie funkcjonujące w świadomości zbiorowej. Ponadto założono, iż interaktywny i swobodny tryb badanej komunikacji może ujawnić naturalną dynamikę w społecznym myśleniu o rzeczywistości (tu o instytucji biblioteki). Drugie z założeń opierało się z kolei na założeniu, iż w tej wymianie wpisy biblioteki i komentarze gości profilu będą generalnie reprezentować dwie nie w pełni tożsame sfery społecznego myślenia, co tworzy i utrzymuje ową dynamikę myślenia w ogóle. Skonfrontowane zostaną więc: $\mathrm{z}$ jednej strony zobiektywizowany społecznie dominujący układ kategorii myślenia o bibliotece (myślenie instytucji biblioteki o sobie), z drugiej subiektywne ekspresje jednostek myślących o bibliotece.

Zakres czasowy analizowanych treści objął okres pełnego roku począwszy od maja 2016 r. do kwietnia 2017 r. W przypadku siedmiu bibliotek średnia częstotliwość publikowania na własnym profilu wynosiła w przybliżeniu jeden post dziennie.

Konkretne liczby wyglądały następująco:

- Biblioteka Główna Uniwersytetu Gdańskiego - 304 wpisy;

- Biblioteka Główna Uniwersytetu Marii Curie-Skłodowskiej w Lublinie - 311 wpisów;

- Biblioteka Jagiellońska - 338 wpisy;

- Biblioteka Uniwersytetu Łódzkiego - 334 wpisy;

- Biblioteka Uniwersytetu Mikołaja Kopernika w Toruniu - 340 wpisów;

- Biblioteka Uniwersytetu Wrocławskiego - 319 wpisów;

- Biblioteka Uniwersytetu Warszawskiego przekraczała nieco wskazaną średnią z 394 wpisami w ciągu analizowanych 12 miesięcy;

- Biblioteka Uniwersytecka Katolickiego Uniwersytetu Lubelskiego Jana Pawła II wypadała z kolei nieco poniżej średniej z 212 wpisami;

- Najwyższą częstotliwość odnotowano na profilu Biblioteki Uniwersytetu Adama Mickiewicza w Poznaniu, na którym opublikowano 765 wpisów w ciągu roku.

Analiza wykonana została z użyciem siatki trzech zbiorów kategorii, które odnosiły się do wpisów publikowanych przez biblioteki. 
Pierwszy zbiór zawierał kategorie określające „Kręgi horyzontów zainteresowań" charakteryzujące publikowane wpisy. Ten zbiór zawierał następujące kategorie treści:

1. Treści o bibliotece.

2. Treści o rodzimej uczelni.

3. Treści o mieście i regionie.

4. Treści o kraju i świecie.

Drugi zbiór zawierał kategorie określające „Obszary tematyczne” charakteryzujące publikowane wpisy. Ten zbiór zawierał następujące kategorie treści:

1. Nauka.

2. Kultura ogólna.

3. Kultura - czytelnictwo.

4. Polityka.

5. Ekonomia.

6. Zdrowie.

7. Życie codzienne.

Trzeci zbiór zawierał kategorie określające „Rodzaje treści” charakteryzujące publikowane wpisy. Ten zbiór zawierał następujące kategorie treści:

1. Informacje.

2. Treści reklamowe.

3. Treści promocyjne i popularyzatorskie (odsyłacze do promocji i popularyzacji).

4. Opinie, polemiki.

5. Analizy.

6. Treści rozrywkowe (konkursy, fotoreportaże; zdjęcia będą zaliczane do kategorii fotoreportażu).

Zestawienie danych $\mathrm{z}$ tego zbioru kategorii zostało przedstawione na rys. 1. Pokazało ono przede wszystkim, że dziewięć analizowanych facebookowych profili bibliotek nie różni się znacząco od siebie. To podobieństwo zostanie potwierdzone $\mathrm{w}$ zestawieniach danych $\mathrm{z}$ dwóch kolejnych zbiorów kategorii. Ponadto w przybliżeniu średnio aż $89 \%$ treści publikowanych na własnym profilu dotyczy biblioteki i rozmaitych spraw związanych z jej funkcjonowaniem. Kolejny horyzont zainteresowań wyznacza życie rodzimej uczelni. W tym przypadku średnio około 7\% treści dotyczyło spraw związanych z rodzimą uczelnią. Pozostałe 4\% było podzielone między sprawy o zasięgu światowym i w końcu krajowym. To przestawienie między naturalną hierarchą horyzontów bliższych i dalszych wynika $\mathrm{z}$ faktu, iż do wydarzeń o zasięgu światowym zaliczono te, które miały w nazwie formułę światowy, światowe ewentualnie międzynarodowy (czyli na przykład Międzynarodowy Dzień Matki). 


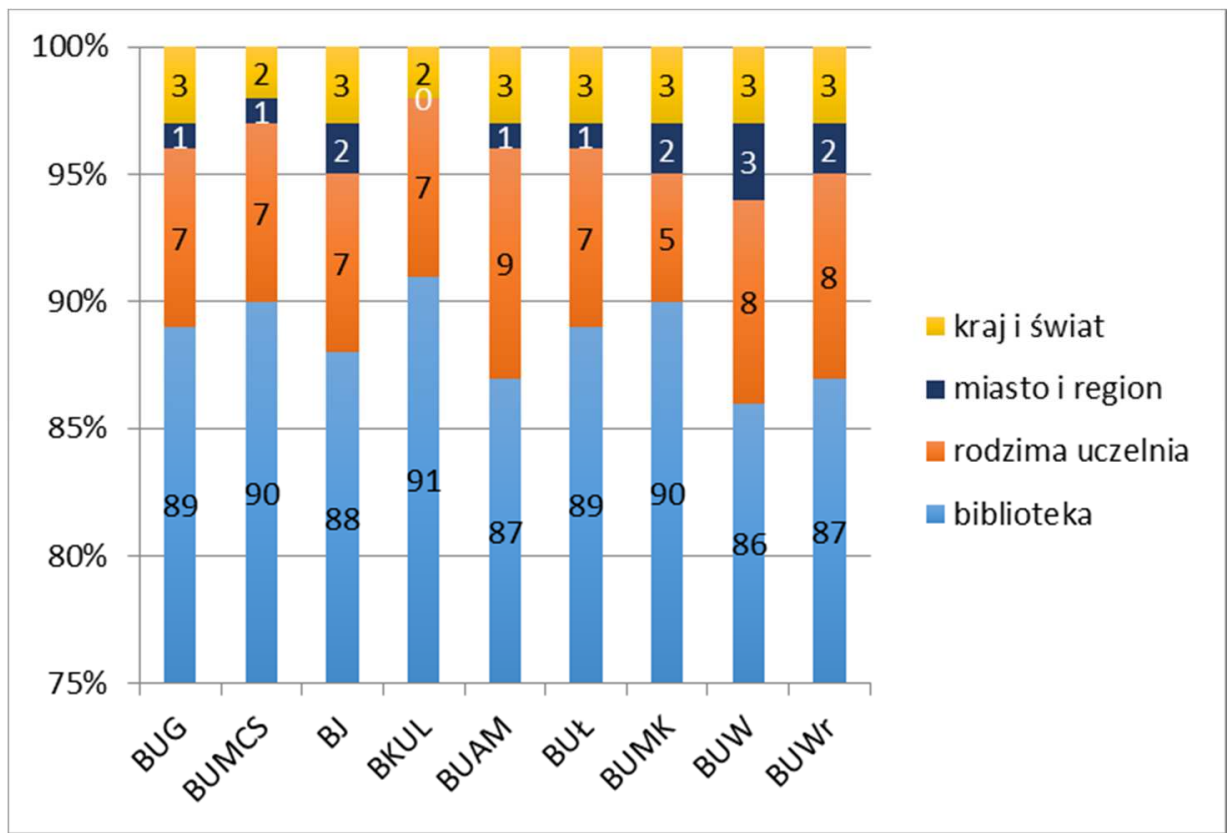

Źródło: badania własne.

Rys. 1. Kręgi horyzontów zainteresowań

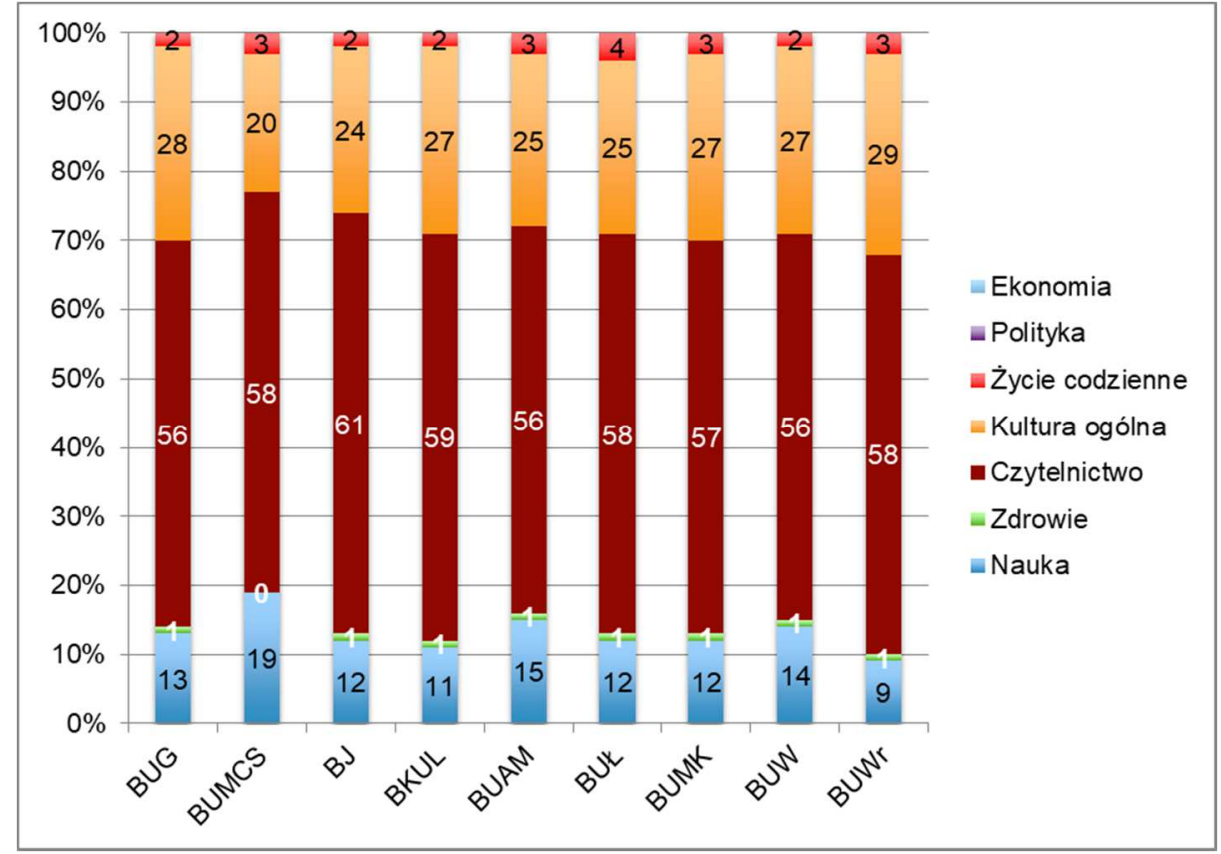

Rys. 2. Obszary tematyczne

Źródło: badania własne. 
Zestawienie danych z kolejnego zbioru kategorii (rys. 2) pokazało, że biblioteki są instytucjami zorientowanymi na działanie specjalistyczne, w związku z czym wyraźnie ponad 50\% (średnio 58\%) publikowanych wpisów zawiera treści o tematyce skoncentrowanej na czytelnictwie, wydawnictwie i tym podobnych. Na drugim miejscu pod względem częstotliwości ukazywania się są wpisy odnoszące się do problematyki kulturalnej (średnio około 26\%). Dopiero na trzecim znalazły się treści, które zaklasyfikowano do kategorii „tematów naukowych" (średnio około 13\%). Z wybranych do analizy 7 kategorii pozostałe 3\% podzieliło się między wpisy o treściach odnoszących się do „życia codziennego" (nieco ponad 2\%) oraz wpisy na temat „zdrowia” (prawie 1\%). Analiza danych z wyznaczonego okresu nie wykazała wpisów na temat „polityki” i „ekonomii”. Te tematy zostały dość zgodnie zignorowane. Tematyka ekonomii może wydawać się zbyt hermetyczna, jednak brak polityki może wiązać się z jej niską społeczną oceną. W przypadku wykorzystania takiego medium jak portal społecznościowy ten ostatni brak może wynikać $\mathrm{z}$ chęci dystansowania się od tematów antagonizujących, kontrowersyjnych i zasadniczo niekonkludywnych, bo za takie uchodzą tematy z obszaru polityki.

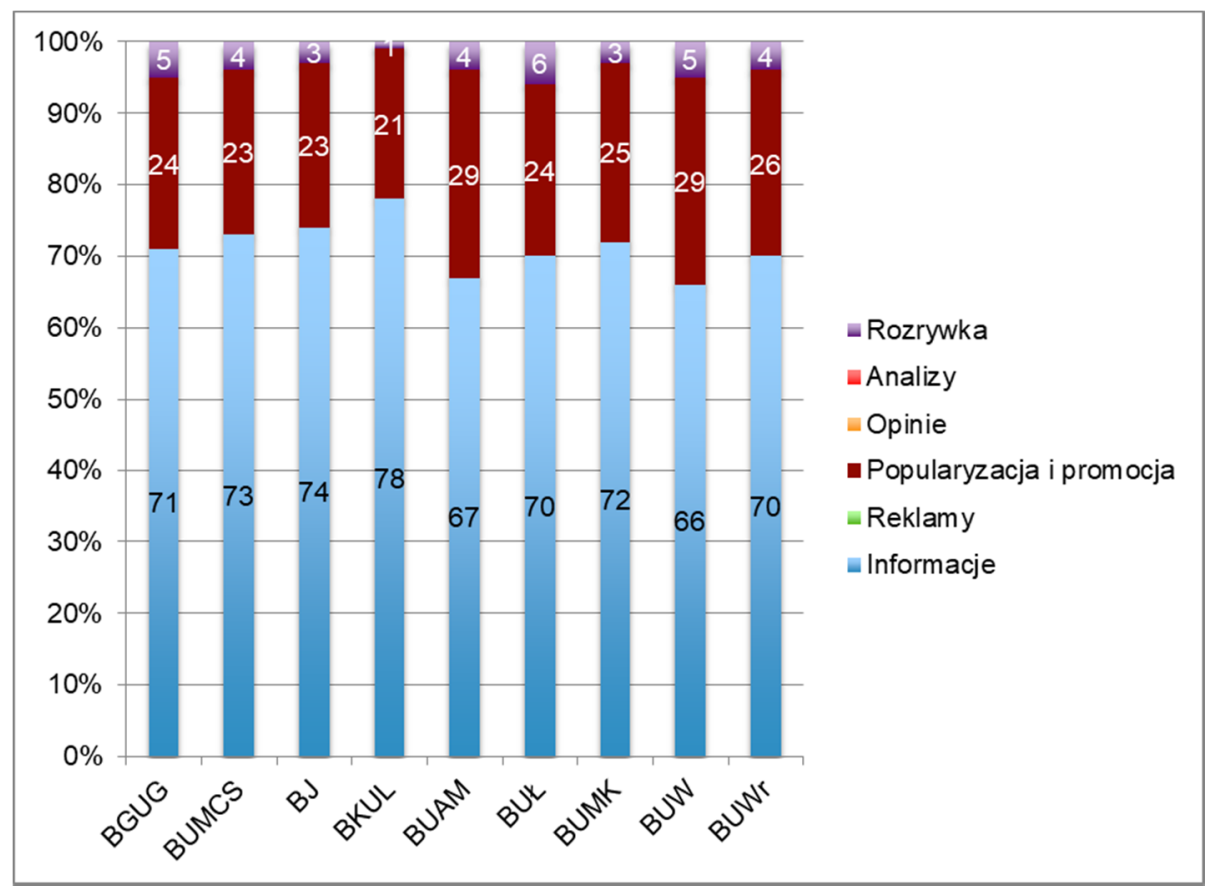

Źródło: badania własne.

Rys. 3. Rodzaje treści 
Zestawienie danych z ostatniego ze zbiorów kategorii (rys. 3) wskazało, że biblioteki wykorzystują profil na Facebooku przede wszystkim do przekazywania informacji (średnio $71 \%$ wpisów). Średnio $25 \%$ wpisów stanowiły treści o charakterze popularyzatorskim. Trzecią kategorią rodzaju treści, której obecność odnotowano na profilu, były treści o charakterze rozrywkowym (średnio $4 \%$ wpisów). Pozostałe 3 rodzaje kategorie rodzajów treści wybranych do analizy nie pojawiały się na profilach badanych bibliotek. Biblioteki nie publikowały więc treści reklamowych, opinii oraz analiz.

Drugą z kwestii istotnych w analizie stylu myślenia o bibliotece, obok kwestii obrazu tworzonego przez samą bibliotekę, była reakcja osób odwiedzających profile biblioteczne na treści tam publikowane. Przede wszystkim należy odnotować stosunkowo niewielką skalę wszystkich reakcji osób odwiedzających profile facebookowe bibliotek. Tak zwane polubienia (like $)^{28}$, wyrażane za pomocą małych obrazków (emotikonów), traktowano w analizie jako czynną reakcję na wpis na profilu (bierną reakcją było samo odczytanie wpisu, którego nie brano tu pod uwagę). Ilość tych czynnych reakcji oscylowała między kilkunastoma a kilkudziesięcioma polubieniami każdego z wpisów. Można więc założyć, że mimo globalnego zasięgu treści internetowych oraz w odniesieniu do liczby potencjalnych czytelników ${ }^{29}$ każdej z badanych bibliotek, profile oddziaływały głównie lokalnie. O ile każdy z wpisów posiadał pewną liczbę polubień, to jedynie w przybliżeniu co dziesiąty był opatrywany pisemnym komentarzem. Ponadto lakoniczność większości opublikowanych komentarzy sprawiała, że znaczenie ich treści zbliżało je do znaczenia treści polubień (na przykład: wpis o treści „Biblioteka dobre miejsce dla człowieka, szczególnie w niedzielę", zamieszczony 5 marca 2017 na profilu Biblioteki Uniwersytetu Łódzkiego, został opatrzony komentarzem „Najlepsze!!!”). Komentarze o rozbudowanej treści pojawiały się głównie pod wpisami o treści rozrywkowej (były to przede wszystkim reakcje na rozmaite konkursy organizowane przez administratorów profili bibliotecznych). Interpretując całość zebranych komentarzy gości profilów bibliotecznych, można powiedzieć, że nie tworzyły one obrazu różniącego się w swym znaczeniu od znaczenia obrazu tworzonego przez wpisy umieszczane na tychże profilach przez ich administratorów.

\footnotetext{
${ }^{28} \mathrm{~W}$ analizie nie różnicowano tych reakcji według 6 kategorii oferowanych przez twórców Facebooka.

${ }^{29}$ Grupę potencjalnych czytelników każdej z akademickich bibliotek stanowią studenci danej uczelni.
} 


\section{Podsumowanie}

Przeprowadzona analiza nie pokazała wpływu Facebooka na sposób myślenia i charakteryzowania instytucji biblioteki, który można by określić jako znaczący. W związku z tym można zaryzykować stwierdzenie, iż zarówno biblioteka, jak też jej użytkownicy, traktują ten portal społecznościowy jako zdigitalizowany i usytuowany w świecie wirtualnym słup ogłoszeniowy, który tym jedynie różni się od swojego klasycznego odpowiednika, iż jest nieco bardziej interaktywny. Czy to oznacza, że zagrożenia wskazywane przez krytyków współczesnego Internetu w rodzaju Wojciecha Orlińskiego nie istnieją? Na to pytanie nie można dać jednoznacznej odpowiedzi w oparciu o przeprowadzone tu badanie. Jego zakres był bowiem zbyt wąski. Jednocześnie już nawet ta niewielka sonda pokazała, iż odporność na zmianę identyfikacji społecznej instytucji takiej jak biblioteka wynika najprawdopodobniej z jej wciąż stosunkowo silnego zestereotypizowania w kategoriach etosu bezinteresowności poznania, misji i służby jej pracowników. Czynniki zmian, na które biblioteka jest wystawiona znajdują się na innych obszarach życia społecznego, raczej w nowych modelach systemowego myślenia o społeczeństwie, takich jak model wolnorynkowy. 